\title{
Is There Any Impact of ST Re-elevation on Patients With Acute Myocardial Infarction Following Reperfusion Therapy?
}

\author{
Kengo Tanabe, MD, PhD
}

$\mathbf{P}$ rimary percutaneous coronary intervention (PCI) to recanalize an occluded artery has been the main treatment for acute myocardial infarction (AMI), but a substantial number of patients still develop large infarcts. Impaired microvascular reperfusion, which is evaluated by the absence of resolution of ST-segment elevation (ST resolution) on the 12-lead ECG following reperfusion therapy, is considered to be associated with worse final TIMI (Thrombolysis in Myocardial Infarction) flow grade and large infarcts. ${ }^{1}$ Furthermore, the measure of ST resolution has been reported to correlate with left ventricular function, survival, and reinfarction during longterm follow-up after both primary PCI and thrombolytic therapy..$^{1-7} \mathrm{ST}$ resolution occurs in $64-85 \%$ of patients, as shown in the Table.

Only a few previous reports have investigated the prevalence of ST segment re-elevation even though ECG is a standard and simple diagnostic modality. Matano et al reported that ST re-elevation occurred in $29 \%$ of the patients, but that there was no difference in ejection fraction (EF) at 1 month between the patients with and without ST re-elevation. ${ }^{4}$ In contrast, Okuda et $\mathrm{al}^{6}$ reported that ST

\section{Article p 1379}

re-elevation, despite initial ST resolution, occurred in 23\% of the patients, and was associated with poorer EF at 6 months. They divided their patients into 3 groups (ST resolution without re-elevation, ST resolution with reelevation, and no ST resolution), and showed the serial ECG changes (Figure). In this issue of the Journal, Cuenin et $\mathrm{a}^{8}$ report that $19 \%$ of 662 patients experienced ST segment re-elevation, but there were no differences in EF or death at 1 year between patients with and without re-elevation. Although the incidence of ST re-elevation was similar to that reported by Okuda et al, the effect on EF was inconsistent. Several differences between the 2 studies may have influenced the results. First, the timing of evaluation for ST re-elevation was different. Most previous studies evaluated ST resolution within several hours after reperfusion therapy, and ST resolution was consistently associated with better clinical outcomes. The mechanism of ST re-elevation is unclear and its occurrence suggests the possibility of re-infarction or pericarditis. In fact, stent

\begin{tabular}{|c|c|c|c|c|c|c|c|c|}
\hline Authors & $\mathbf{n}$ & Year & $\begin{array}{l}\text { Timing of ST } \\
\text { resolution } \\
\text { assessment }\end{array}$ & $\begin{array}{l}\text { Incidence } \\
\text { of ST } \\
\text { resolution }\end{array}$ & $\begin{array}{l}\text { Timing of ST } \\
\text { re-elevation } \\
\text { assessment }\end{array}$ & $\begin{array}{l}\text { Incidence } \\
\text { of ST } \\
\text { re-elevation }\end{array}$ & Follow-up & Outcome \\
\hline $\begin{array}{l}\text { van't Hof } \\
\text { et al }{ }^{7}\end{array}$ & 403 & 1997 & $1 \mathrm{~h}$ after & $85 \%$ & NA & NA & 3.1 years & $\begin{array}{l}\text { Resolution: better } \\
\text { survival }\end{array}$ \\
\hline $\begin{array}{l}\text { Matetzky } \\
\text { et } \mathrm{al}^{5}\end{array}$ & 117 & 1999 & $1 \mathrm{~h}$ after & $76 \%$ & NA & NA & 2.5 years & $\begin{array}{l}\text { Resolution: better } \\
\text { survival }\end{array}$ \\
\hline $\begin{array}{l}\text { Claeys } \\
\text { et al }{ }^{1}\end{array}$ & 91 & 1999 & $\begin{array}{l}\text { At the end of } \\
\text { PCl }\end{array}$ & $64 \%$ & NA & NA & 1 year & $\begin{array}{l}\text { Resolution: better } \\
\text { survival }\end{array}$ \\
\hline $\begin{array}{l}\text { Matano } \\
\text { et } \mathrm{al}^{4}\end{array}$ & 51 & 2002 & First day & NA & $\begin{array}{l}\text { Once daily } \\
\text { until 7days }\end{array}$ & $29 \%$ & 1 month & $\begin{array}{l}\text { Re-elevation: no } \\
\text { difference (EF) }\end{array}$ \\
\hline $\begin{array}{l}\text { Brodie } \\
\text { et } \mathrm{al}^{2}\end{array}$ & 1,005 & 2005 & $<4 \mathrm{~h}$ after $\mathrm{PCl}$ & $85 \%$ & NA & NA & 6.2 years & $\begin{array}{l}\text { Resolution: better } \\
\text { survival }\end{array}$ \\
\hline $\begin{array}{l}\text { Okuda } \\
\text { et al }{ }^{6}\end{array}$ & 164 & 2008 & $1 \mathrm{~h}$ after $\mathrm{PCl}$ & $73 \%$ & $24 \mathrm{~h}$ after & $23 \%$ & 6 months & $\begin{array}{l}\text { Resolution without } \\
\text { re-elevation best EF }\end{array}$ \\
\hline $\begin{array}{l}\text { Cuenin } \\
\text { et al }\left.\right|^{8}\end{array}$ & 662 & 2018 & $1-1.5 \mathrm{~h}$ after & $77 \%$ & 5 days & $19 \%$ & 1 year & $\begin{array}{l}\text { Resolution: better } \\
\text { survival, re-elevation: } \\
\text { no difference (EF) }\end{array}$ \\
\hline
\end{tabular}

EF, ejection fraction; NA, not applicable.

The opinions expressed in this article are not necessarily those of the editors or of the Japanese Circulation Society.

Received March 18, 2018; accepted March 19, 2018; released online April 5, 2018

Division of Cardiology, Mitsui Memorial Hospital, Tokyo, Japan

Mailing address: Kengo Tanabe, MD, PhD, Division of Cardiology, Mitsui Memorial Hospital, 1, Kanda-Izumicho, Chiyoda-ku, Tokyo 101-8643, Japan. E-mail: kengo-t@zd5.so-net.ne.jp

ISSN-1346-9843 All rights are reserved to the Japanese Circulation Society. For permissions, please e-mail: cj@j-circ.or.jp 


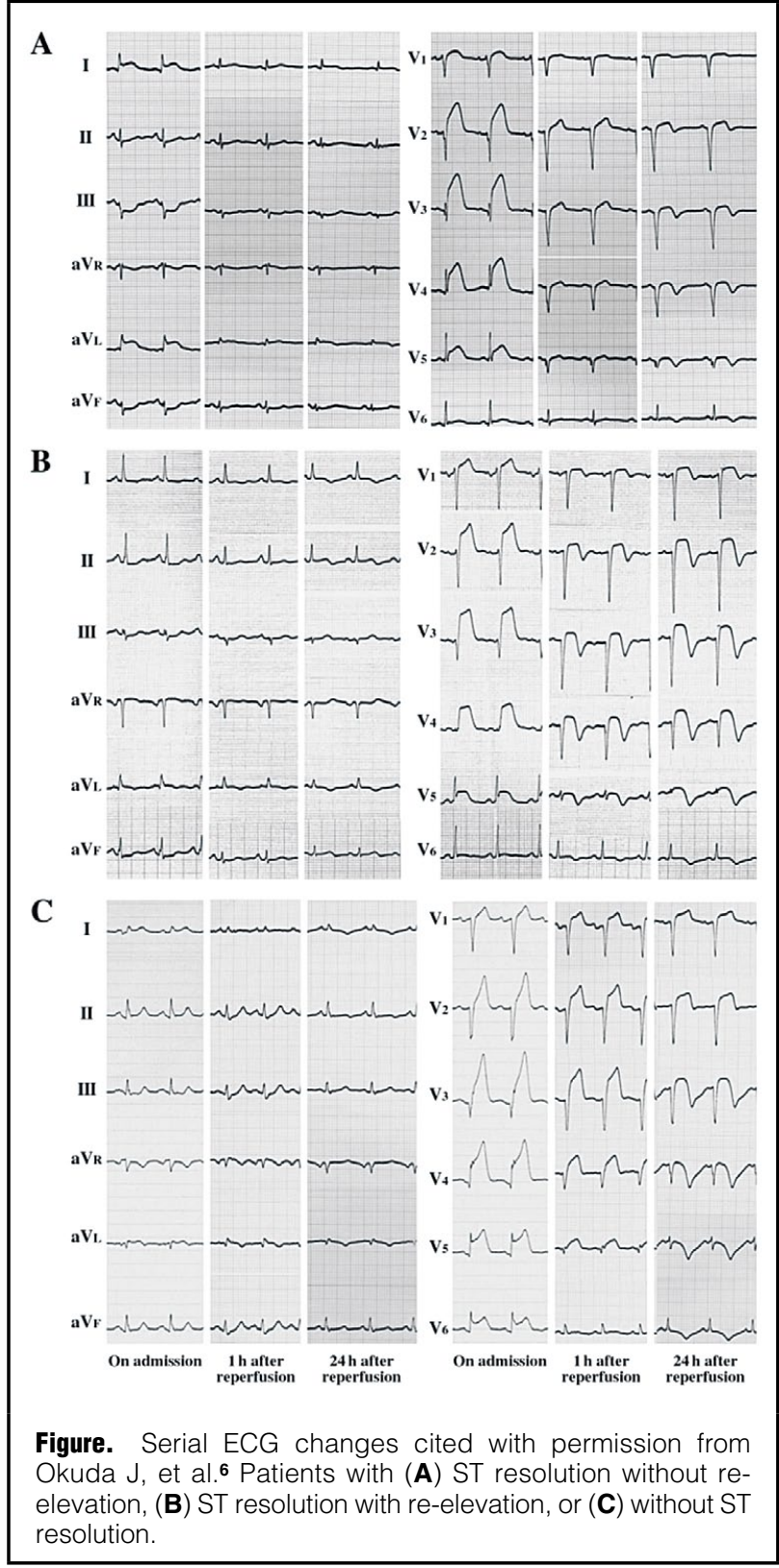

thrombosis and pericarditis were present in 0.8 and $9.4 \%$ of cases, respectively, in the report by Cuenin et al. ${ }^{8}$ It is noteworthy that their results were similar after exclusion of all patients with stent thrombosis and pericarditis. As discussed by Cuenin et al, infarct expansion, reperfusion injury, inflammatory response, and edema may play a role in ST re-elevation. The timing of these phenomena following reperfusion therapy could differ, so the different time points used to assess ST re-elevation in the 2 studies may explain the conflicting results. Second, Cuenin et al included patients with an absence of initial ST resolution in their ST reelevation group. However, considering that an absence of $\mathrm{ST}$ resolution is associated with worse EF, this point is unlikely to explain the different outcomes. Third, primary PCI was performed in only $60 \%$ of the patients in the report by Okuda et al, compared with all patients in the report by Cuenin et al. The different reperfusion strategy might have affected the results.

Cuenin et al makes us realize that surprisingly few reports have investigated the significance of ST segment re-elevation following primary PCI, even though ECG is a simple and accepted tool. In addition, the newer generation drug-eluting stents demonstrate superior clinical outcomes as compared with bare-metal stents. ${ }^{9,10}$ Further studies in the current PCI era are warranted to determine the effect of ST re-elevation on patients with AMI following primary PCI.

\section{Conflicts of Interest}

The author received remuneration from Abbott Vascular, Kaneka, Daiichisankyo, and Terumo.

\section{References}

1. Claeys MJ, Bosmans J, Veenstra L, Jorens P, De Raedt H, Vrints CJ. Determinants and prognostic implications of persistent STsegment elevation after primary angioplasty for acute myocardial infarction: Importance of microvascular reperfusion injury on clinical outcome. Circulation 1999; 99: 1972-1977.

2. Brodie BR, Stuckey TD, Hansen C, VerSteeg DS, Muncy DB, Moore S, et al. Relation between electrocardiographic ST-segment resolution and early and late outcomes after primary percutaneous coronary intervention for acute myocardial infarction. Am J Cardiol 2005; 95: 343-348.

3. McLaughlin MG, Stone GW, Aymong E, Gardner G, Mehran $\mathrm{R}$, Lansky AJ, et al. Prognostic utility of comparative methods for assessment of ST-segment resolution after primary angioplasty for acute myocardial infarction: The Controlled Abciximab and Device Investigation to Lower Late Angioplasty Complications (CADILLAC) trial. J Am Coll Cardiol 2004; 44: 1215-1223.

4. Matano S, Iwasaki K, Kusachi S, Murakami T, Kurazono S, Yamaji $\mathrm{H}$, et al. ST-segment re-elevation unrelated to left ventricular ejection fraction or volume after anterior wall acute myocardial infarction treated with successful reperfusion. $J$ Electrocardiol 2002; 35: 87-93.

5. Matetzky S, Novikov M, Gruberg L, Freimark D, Feinberg M, Elian D, et al. The significance of persistent ST elevation versus early resolution of ST segment elevation after primary PTCA. $J$ Am Coll Cardiol 1999; 34: 1932-1938.

6. Okuda J, Kosuge M, Ebina T, Hibi K, Tsukahara K, Iwahashi $\mathrm{N}$, et al. Clinical implications of serial changes in ST-segment elevation after reperfusion in patients with anterior acute myocardial infarction. Circ J 2008; 72: 409-414.

7. van't Hof AW, Liem A, de Boer MJ, Zijlstra F. Clinical value of 12-lead electrocardiogram after successful reperfusion therapy for acute myocardial infarction: Zwolle Myocardial Infarction Study Group. Lancet 1997; 350: 615-619.

8. Cuenin L, Lamoureux S, Schaaf M, Bochaton T, Monassier JP, Claeys MJ, et al. Incidence and significance of spontaneous ST segment re-elevation after reperfused anterior acute myocardial infarction: Relationship with infarct size, adverse remodeling, and events at 1 year. Circ J 2018; 82: 1379-1386.

9. Raber L, Kelbaek H, Ostojic M, Baumbach A, Heg D, Tuller D, et al. Effect of biolimus-eluting stents with biodegradable polymer vs bare-metal stents on cardiovascular events among patients with acute myocardial infarction: The COMFORTABLE AMI randomized trial. JAMA 2012; 308: 777-787.

10. Sabate M, Cequier A, Iniguez A, Serra A, Hernandez-Antolin R, Mainar V, et al. Everolimus-eluting stent versus bare-metal stent in ST-segment elevation myocardial infarction (EXAMINATION): 1 year results of a randomised controlled trial. Lancet 2012; 380: $1482-1490$. 